\title{
PENGELOLAAN MANAJEMEN SUMBER DAYA
}

\section{MANUSIA}

Makalah ini Disusun untuk memenuhi Tugas pada Mata Kuliah

Kewirusahaan

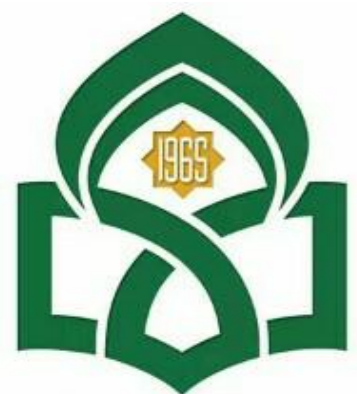

UNIVERSITAS ISLAM NEGERI

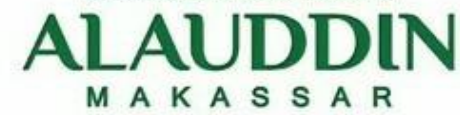

Oleh :

GUSTI YUSMIANA

90500120109

FAKULTAS EKONOMI DAN BISNIS ISLAM

UNIVERSITAS ISLAM NEGERI ALAUDDIN MAKASSAR

2020/2021 


\begin{abstract}
ABSTRAK
Sumber Daya Manusia (SDM) merupakan salah satu faktor terpenting yang tidak dapat dipisahkan baik dari organisasi maupun perusahaan, dan SDM juga merupakan kunci perkembangan perusahaan. Pada hakekatnya sumber daya manusia ( orang-orang ) dapat digunakan sebagai pelaku, pemikir, dan perencana dalam suatu organisasi untuk mencapai tujuan organisasi. Manajemen sumber daya manusia suatu organisasi memiliki satu tujuan umum. Hal ini dapat memastikan bahwa tenaga kerja yang terampil, berdedikasi dan termotivasi yang dibutuhkan organisasi diterima dan dipelihara. Pengembangan SDM merupakan salah satu bentuk upaya buat menaikkan kemampuan karyawan pada menangani majemuk jenis tugas \& menerapkan kemampuan yg diperlukan sinkron menggunakan jenis pekerjaan yg ada.
\end{abstract}

Kata Kunci : Manajemen, Sumber, Daya, Manusia 


\section{KATA PENGANTAR}

Puji syukur kita panjatkan kepada Tuhan Yang Maha Esa karena atas rahmat dan karunia-Nya kita dapat menyelesaian makalah "Pengelolaan Manajemen Sumber Daya Manusia”. Dan saya berterima kasih kepada ibu Dra. Hj. Nuraeni Gani, MM. sebagai Dosen mata kuliah kewirausahaan yang telah memberikan tugas kepada saya

Saya sangat berharap makalah ini dapat berguna dalam rangka menambah wawasan serta pengetahuan kita sebagai penulis maupun pembaca. Saya menyadari bahwa dalam penulisan makalah ini masih terdapat banyak kekurangan dan jauh dari apa yang kami harapkan. Saya mohon maaf apabila terdapat kesalahan kata kata yang kurang berkenan dalam penulisan makalah ini. Oleh karena itu saya mengharapkan kritik dan saran yang membangun untuk menyempurnakan makalah ini untuk menjadi lebih baik lagi.

Wajo, 20 November 2021

Penulis 


\section{DAFTAR ISI}

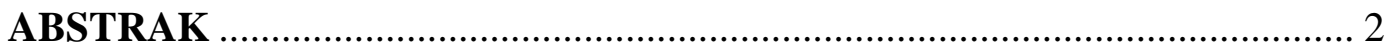

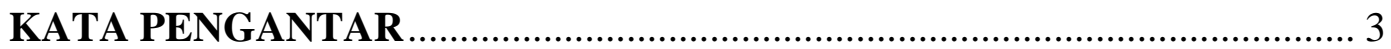

DAFTAR ISI

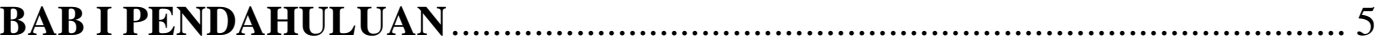

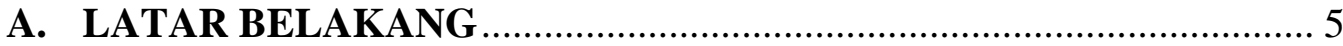

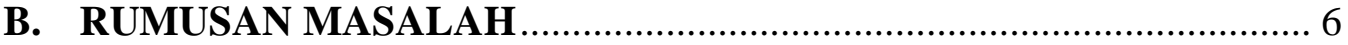

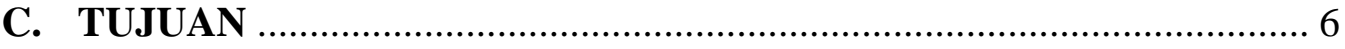

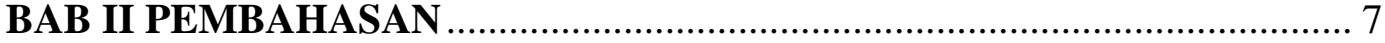

1. Pengertian Manajemen Sumber Daya Manusia ................................ 7

2. Tujuan \& Peran Manajemen Sumber Daya Manusia......................... 8

3. Fungsi Manajemen Sumber Daya Manusia ....................................... 9

4. Tahapan dan Perkembangan Manajemen Sumber Daya Manusia di

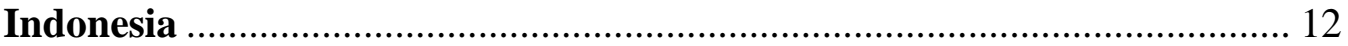

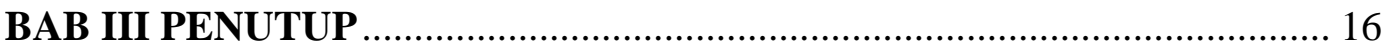

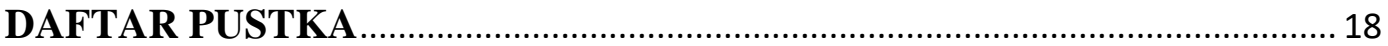




\section{BAB I \\ PENDAHULUAN}

\section{A. LATAR BELAKANG}

Manajemen sumber daya manusia terdiri dari istilah manajemen dan sumber daya manusia. Dimana manajemen ini dapat mengatur proses sumber daya manusia secara efektif dan efisien mengelola proses yang menggunakan manusia dan sumber daya lainnya untuk mencapai tujuan tertentu. Manajemen Sumber Daya Manusia adalah ilmu dan seni yang mengatur hubungan dan peran tenaga kerja agar bisa menjadi tujuan yang efektif dan efisien bagi terwujudnya tujuan perusahaan, dan bagi pelaku ( tenaga kerja) selalu berperan aktif dalam kegiatan perusahaan/usaha. Sumber daya manusia sebagai salah satu sumber daya dalam suatu organisasi memegang peranan penting dalam mencapai tujuan perusahaan.

Sumber daya manusia sebagai salah satu sumber daya yang ada dalam suatu organisasi memegang peranan penting dalam keberhasilan pencapaian tujuan perusahaan. Dimana sumber daya manusia menggunakan sumber daya lain yang dimiliki oleh organisasi untuk mencapai tujuannya. Bahkan mesin berteknologi tinggi tidak masuk akal kecuali orang yang menjalankannya memenuhi syarat untuk melakukannya. Sumber daya manusia merupakan area sentral dan penting dalam mencapai tujuan perusahaan. Keterampilan karyawan dan kualitas bakat mereka dapat membantu perusahaan menjalankan perusahaan dengan baik dan benar. 


\section{B. RUMUSAN MASALAH}

1. Jelaskan pengertian manajemen sumber daya manusia?

2. Bagaimana tujuan \& Peran manajemen sumber daya manusia?

3. Bagaimana fungsi manajemen sumber daya manusia ?

4. Bagaimana tahapan dan perkembangan manajemen sumber daya manusia Indonesia?

\section{TUJUAN}

1. Untuk mengetahui pengertian manajemen sumber daya manusia?

2. Untuk mengetahui tentang tujuan dan peran manajemen sumber daya manusia?

3. Untuk mengetahui tentang fungsi manajemen sumber daya manusia?

4. Untuk mengetahui tahapan dan perkembangan manajemen sumber daya manusia di Indonesia. 


\section{BAB II \\ PEMBAHASAN}

\section{Pengertian Manajemen Sumber Daya Manusia}

Menurut Nawawi memberikan pengertian sumber daya manusia sebagai berikut :

a) Sumber daya mansuia adalah manusia yang bekerja di lingkungan organisasi.

b) Sumber daya manusia adalah potensi sebagai penggerak organisasi dalam mewujudkan eksistensinya.

c) Sumber daya manusia merupakan asset dan berfungsi sebagai modal

Sedangkan menurut pendapat dari Hasibuan, sumber daya manusia (SDM) merupakan ilmu dan seni mengatur hubungan dan peranan tenaga kerja agar efektif dan efisien membantu terwujudnya tujuan perusahaan, karyawan dan masyarakat.

Sumber Daya Manusia (SDM) merupakan salah satu faktor terpenting yang tidak dapat dipisahkan baik dari organisasi maupun perusahaan, dan SDM juga merupakan kunci perkembangan perusahaan. Pada hakekatnya sumber daya manusia ( orang-orang ) dapat digunakan sebagai pelaku, pemikir, dan perencana dalam suatu organisasi untuk mencapai tujuan organisasi. Beberapa pengertian di atas, dapat disimpulkan bahwa sumber daya manusia adalah salah satu sumber daya yang termasuk dalam suatu organisasi, dimana semua yang melaksanakan kegiatan memiliki akal, emosi, keinginan, motivasi, keterampilan, kemampuan, pengetahuan, dan pekerjaan, sehingga merupakan tempat untuk mengakumulasi daya.

Hubungan manajemen dan sumber daya manusia merupakan proses untuk mencapai tujuan melalui kerjasama dengan pihak lain. Ini berarti menunjukkan penggunaan sumber daya orang lain untuk mencapai tujuan mereka. Sumber daya manusia merupakan faktor terpenting dalam proses pembangunan. Bukan hanya 
peran sumber daya manusia dalam pembangunan yang aktif, tetapi kesadaran diri tanpa tekanan dari luar atau pihak lain. Hal ini merupakan esensi dari peran sumber daya manusia dalam pembangunan yang sebenarnya diharapkan.

\section{Tujuan \& Peran Manajemen Sumber Daya Manusia}

\section{Tujuan Manajemen Sumber Daya Manusia}

Manajemen sumber daya manusia yang mengatur potensi sumber daya dalam suatu organisasi untuk mencapai tujuan perusahaan. Ada dua hal penting dalam manajemen yaitu manusia dan organisasi. Dimana manusia merupakan potensi yang melakukan kegiatan manajemen dan organisasi yaitu menyalurkan potensi sumber daya manusia dalam mencapai kemakmuran bersama.

Manajemen sumber daya manusia suatu organisasi memiliki satu tujuan umum. Hal ini dapat memastikan bahwa tenaga kerja yang terampil, berdedikasi dan termotivasi yang dibutuhkan organisasi diterima dan dipelihara. Dimana manajemen perlu mengambil langkah-langkah untuk menilai dan memenuhi kebutuhan masa depan masyarakat serta meningkatkan dan mengembangkan keterampilan unik mereka dengan memberikan kesempatan belajar dan pengembangan yang berkelanjutan. Jadi disimpulannya bahwa pentingnya pengelolaan sumber daya manusia dalam suatu organisasi adalah untuk memastikan bahwa kinerja organisasi tercapai sesuai dengan apa yang di rencanakan oleh orang-orang dalam organisasi tersebut. Maka orang-orang yang dapat belajar, berubah, berinovasi, memberikan dorongan kreatif, termotivasi, dan menjamin kelangsungan hidup jangka panjang dalam organisasi.

\section{Peran Manajemen Sumber Daya Manusia}


Menurut Mathis \& Jackson (2010), peran penting manajemen sumber daya dapat dilihat dari tiga aspek penting: peran administratif, peran operasional, dan peran strategis. Kegiatan dalam masing-masing peran tersebut memiliki jenis kegiatan yang berbeda dengan tujuan yang berbeda pula. Ketiga peran tersebut dapat dijelaskan sebagai berikut:

- Peran administratif; berfokus pada administrasi pencatatan dan pembukuan, termasuk dokumen penting dan implementasi kebijakan. Peran ini bertujuan untuk melengkapi kebutuhan administrasi guna mendukung kegiatan operasional dan strategis yang ditetapkan.

- Peran operasional; berfokus pada pengelolaan sebagian besar aktivitas sumber daya manusia agar sejalan dengan strategi dan operasi yang telah ditetapkan oleh manajemen. Peran ini memiliki tujuan untuk memastikan jalannya operasional lapangan sesuai dengan tujuan strategi organisasi.

- Peran strategis; berfokus membantu mendefinisikan strategi organisasi terhadap sumber daya manusia dan kontribusinya pada hasil dari tujuan organisasi. Peran ini bertujuan untuk melakukan pendampingan dalam penerapan rencana strategis ke dalam aktivitas pelaksanaannya di tingkat operasional.

\section{Fungsi Manajemen Sumber Daya Manusia}

Manajemen SDM memiliki fungsi penting bagi suatu organisasi tidak hanya pada level manajerialnya tetapi juga pada level operasional. Danang Sunyoto (2012) menyebutkan bahwa kedua fungsi tersebut memiliki landasan kuat untuk bahan pijakan pada penerapan atau praktik yang diterapkan dalam organisasi. Dalam hal ini adapun ungsi-fungsi dimaksud yaitu :

a. Dalam fungsi manajerial ini dibagi menjadi empat bidang yaitu perencanaan, pengorganisasian, pengarahan dan pengendalian. 
- Perencanaan, meliputi penentuan program pengelolaan sumber daya manusia yang akan membantu pencapaian tujuan organisasi. Sehingga fungsi ini mencakup perencanaan jangka pendek dan jangka Panjang, dimana sejak awal terkait erat dengan kelancaran suatu organisasi di dalamnya.

- Organize, membentuk organisasi dengan mengkoordinir berbagai hubungan antar jabatan, proses kerja, aktivitas personalia, dan faktor lainnya.

- Pengarahan. Memotivasi karyawan untuk bekerja secara efektif melalui pemberian tugas, motivasi, dan aturan yang mengikat.

- Pengendalian Mengamati pelaksanaan langkah kerja, membandingkannya dengan rencana, mengoreksi penyimpangan atau bila perlu menyesuaikan kembali rencana yang dibuat.

b. Sedangkan dalam fungsi operasional, dapat dibagi menjadi 6 kegiatan : pengadaan, pengembangan, kompensasi, integrasi, pemeliharaan, dan pemutusan hubungan kerja yaitu :

- Fungsi pengadaan meliputi kegiatan perencanaan personalia, rekrutmen, seleksi, penempatan dan orientasi, perencanaan mutu, dan jumlah pegawai. Dalam rekrutmen, seleksi dan penempatan berkaitan dengan penarikan lamaran, seleksi, persiapan, evaluasi, psikotes, dan wawancara kerja. Fungsi ini bermanfaat untuk mendapatkan jenis, komposisi, dan jumlah sumber daya yang tepat yang dibutuhkan untuk mencapai tujuan organisasi

- Fungsi pengembangan dimaksudkan untuk meningkatkan keterampilan, pengetahuan, sikap, atau perilaku kerja karyawan agar dapat melaksanakan tugasnya dengan baik. Kegiatan ini menjadi lebih penting karena tugas manajer dalam program pengembangan karyawan tumbuh dan menjadi lebih kompleks. Peran ini terkait dengan peningkatan keterampilan dan kemampuan yang ditempuh melalui pendidikan dan pelatihan sumber daya manusia, serta berbagai bentuk pengembangan diri karyawan yang bertalenta. 
- Fungsi kompensasi dapat didefinisikan sebagai kompensasi yang adil dan rasional sebagai kompensasi atas pekerjaan seorang karyawan. Penghargaan adalah salah satu tugas yang paling kompleks dan pada saat yang sama salah satu aspek yang paling berarti bagi karyawan dan organisasi.

- Fungsi integrasi karyawan ini mencakup upaya untuk mengkoordinasikan kepentingan individu karyawan, organisasi, dan masyarakat. Perusahaan perlu memahami sikap dan emosi karyawannya untuk mempertimbangkannya saat mengambil keputusan.

- Fungsi pemeliharaan seharusnya tidak hanya mencegah hilangnya karyawan karena pemecatan, tetapi juga menjaga sikap kooperatif dan kemampuan karyawan. Peran ini terkait dengan upaya menjaga kesiapan dan kemampuan kerja pegawai melalui pelaksanaan beberapa program yang dapat meningkatkan loyalitas dan kebanggaan dalam bekerja.

- Pemutusan hubungan kerja, yaitu pemutusan hubungan kerja dengan karyawan dan kembali ke masyarakat. Proses pemberhentian yang utama adalah pensiun, pemberhentian, pengunduran diri, dan pemecatan.

Dari ciri-ciri tersebut, terlihat jelas adanya hubungan antara satu fungsi dengan fungsi lainnya dan aktivitas yang dilakukan oleh manajemen sumber daya manusia. Semua fungsi tersebut saling terkait dan memiliki fungsi yang sama yang bertujuan untuk meningkatkan produktivitas karyawan. 


\section{Tahapan dan Perkembangan Manajemen Sumber Daya Manusia di Indonesia}

\section{$>$ Proses Tahapan dalam Manajemen Sumber Daya Manusia}

\section{Rekrutmen (Procurement)}

HR Procurement Rekrutmen disini berarti pengadaan, proses pengisian lowongan, mulai dari perencanaan, periklanan, lamaran, seleksi hingga pengangkatan dan penempatan. Pengadaan yang dimaksud disini lebih luas karena pengadaan dapat menjadi salah satu upaya pemulihan. Oleh karena itu, pengadaan disini merupakan upaya untuk mencari kandidat dari dalam atau luar perusahaan untuk mengisi posisi yang membutuhkan tenaga yang berkualitas.

Rekrutmen dari dalam perusahaan merupakan bagian dari upaya pemanfaatan sumber daya manusia yang ada, seperti mutasi, terlepas dari dipromosikan atau tidak. Tahap seleksi memegang peranan penting dalam merekrut dari luar perusahaan. Pilihan yang direkomendasikan adalah standar yang terukur (measurable) dan persaingan terbuka berdasarkan kualitas. Baik untuk promosi maupun non-promosi, salah satu faktor yang perlu dipertimbangkan ketika memilih pekerja baru dan mutasi adalah faktor. Kemampuan, kompetensi, keterampilan, kepribadian, kecakapan dan pengetahuan, Fase memiliki peran penting dan merupakan tugas utama manajer. Di sini, penting untuk mendayagunakan sumber daya manusia dan tenaga kerja secara efisien, atau memanfaatkan sumber daya manusia secara optimal. Artinya, bakat ditempatkan sesentral mungkin, tetapi batas potensi pekerjaan yang berarti dipenuhi dan dipertimbangkan. Orang tidak merasa ditekan karena mereka secara alami menikmati kepentingan mereka sendiri.

Prinsip memaksimalkan sumber daya manusia adalah prinsip kepuasan, yaitu kepuasan karyawan, yang merupakan kekuatan 
pendorong di balik kinerja yang lebih tinggi, karena lebih bermanfaat bagi organisasi dan pemangku kepentingan lainnya. .. Penggunaan sumber daya manusia dapat dilakukan dengan berbagai cara, dari yang paling sederhana dan paling sederhana hingga yang paling canggih. Penggunaan sumber daya manusia harus sudah dimulai pada tahap pengadaan. Ini menerapkan prinsip orang yang tepat di tempat kerja yang tepat

\section{Pemeliharaan}

Pemeliharaan atau servis menjadi tanggung jawab masing-masing manajer. Mempertahankan personel dengan sistem penghargaan mempengaruhi operasi organisasi. Tujuan utama dari pemeliharaan adalah untuk memungkinkan orang-orang dalam organisasi untuk bersantai, bertahan dan memainkan peran yang optimal. Orang yang tidak diperhatikan dan merasa tidak menerima kompensasi yang adil atau wajar dapat membuat karyawan keluar dari perusahaan atau tidak dapat bekerja secara maksimal.

Konservasi sumber daya manusia pada dasarnya berarti memperhatikan kemanusiaan dan mempertimbangkannya dengan cermat. Biaya pegawai harus diimbangi dengan sistem kompensasi berupa gaji, tunjangan dan sumber keuangan lainnya, atau hal-hal penting seperti: Bentuk tidak berwujud seperti peralatan kendaraan, perubahan, pemrosesan, dan peluang pendidikan dan pelatihan. Mempertahankan sistem ini diharapkan dapat mempengaruhi tingkat kinerja dan produktivitas tenaga kerja.

\section{Pemgembangan}

Dalam pengembangan sumber daya manusia disuatu organisasi perlu dilakukan sejalan dengan perkembangan organisasi tersebut sampai batas tertentu. Pengembangan sumber daya manusia dapat dilakukan melalui pendidikan dan pelatihan yang berkesinambungan. Pendidikan 
dan pelatihan berupaya untuk mengembangkan sumber daya manusia, terutama kemampuan intelektual dan kepribadian.

Pendidikan pada umumnya mencakup penyiapan pekerja masa depan untuk bekerja dalam suatu organisasi, tetapi pendidikan bertujuan untuk meningkatkan keterampilan atau kemampuan pekerja yang telah memenuhi posisi atau tugas tertentu.

\section{Perkembangan Sumber Daya Manusia}

Situasi Sumber Daya Manusia (SDM) di Era Krisis Ekonomi Dampak Krisis Ekonomi Paruh Kedua Tahun 1997 yang melanda negara-negara Asia juga berimbas ke Indonesia. Keadaan ini juga menyebabkan kemerosotan masyarakat Indonesia yang berujung pada meningkatnya angka kemiskinan di Indonesia. Krisis multi-ekonomi ini memberikan sedikit kesempatan kerja, terutama bagi lulusan perguruan tinggi. Di sisi lain, jumlah lulusan perguruan tinggi terus meningkat.

Resesi jangka panjang menunjukkan bahwa fondasi ekonomi Indonesia dan masyarakat yang dikandungnya tidak cukup kuat untuk menahan goncangan ekonomi eksternal dan perkembangan globalisasi dalam tatanan moral negara. Globalisasi ekonomi yang ditandai dengan globalisasi ekonomi sumber daya manusia pada abad 21 merupakan kegiatan ekonomi dan perdagangan yang menjadi kekuatan pasar yang mengintegrasikan negara-negara di seluruh dunia tanpa hambatan lintas batas negara. Globalisasi tentunya dihadapi masyarakat Indonesia yang menuntut efisiensi dan daya saing di dunia usaha.

Kualitas SDM di Indonesia tidak kalah bersaing pada kancah Internasional pada beberapa bidang eksklusif \& output karyanya pun bisa diandalkan. Tetapi secara holistik kualitas \& kemampuan asal daya insan Indonesia masih wajib terus ditingkatkan. Pengembangan sumber daya manusia dalam persaingan dunia yg semakin menajam, pengembangan SDM adalah suatu bisnis yg sangat krusial \& diperlukan buat bisa bersaing pada kancah perdagangan/ persaingan Internasional. Pengembangan SDM 
merupakan salah satu bentuk upaya buat menaikkan kemampuan karyawan pada menangani majemuk jenis tugas \& menerapkan kemampuan yg diperlukan sinkron menggunakan jenis pekerjaan yg ada. Usaha pengembangan berguna bagi organisasi \& individu karyawan. Kemampuan \& pengalaman yg sempurna menurut karyawan \& manajer bisa memperkuat daya saing organisasi \& kemampuan buat mengadaptasi terhadap lingkungan yg berubah khususnya bila terjadi turbulensi eksternal. Bagi individu karyawan, acara pengembangan diantaranya membuka peluang buat kenaikan pangkat karir. Salah satu bentuk menurut pengembangan SDM merupakan training. Dalam prakteknya training disandingkan menggunakan pengembangan. Pengembangan tidak selaras menggunakan training baik dipandang menurut segi fokus, jangka waktu, \& berukuran efektifitas. Fokus training dalam belajar aktivitas \& konduite spesifik; mendemonstrasi teknik \& proses. Sementara pengembangan dalam tahu konsep \& konteks informasi; pengembangan pendapat; pengembangan kapasitas buat menjalankan tugas. 


\section{BAB III \\ PENUTUP}

\section{KESIMPULAN}

Manajemen dan sumber daya manusia merupakan proses untuk mencapai tujuan melalui kerjasama dengan pihak lain. Ini berarti menunjukkan penggunaan sumber daya orang lain untuk mencapai tujuan mereka. Sumber daya manusia merupakan faktor terpenting dalam proses pembangunan. Ada dua hal penting dalam manajemen yaitu manusia dan organisasi. Dimana manusia merupakan potensi yang melakukan kegiatan manajemen dan organisasi yaitu menyalurkan potensi sumber daya manusia dalam mencapai kemakmuran bersama. Peran penting manajemen sumber daya dapat dilihat dari tiga aspek penting: peran administratif, peran operasional, dan peran strategis. Semua fungsi tersebut saling terkait dan memiliki fungsi yang sama yang bertujuan untuk meningkatkan produktivitas karyawan. Pengembangan sumber daya manusia dalam persaingan dunia yg semakin menajam, pengembangan SDM adalah suatu bisnis yg sangat krusial \& diperlukan buat bisa bersaing pada kancah perdagangan/ persaingan Internasional. 


\section{SARAN}

Penulis berharap makalah ini dapat memberikan wawasan kepada seluruh mahasiswa khususnya bagi pembaca, dan memotivasi mereka untuk lebih meningkatkan kualitas talenta perusahaan. Kritik dan saran yang membangun sangat kami harapkan untuk penyempurnaan karya ini. 


\section{DAFTAR PUSTKA}

Hasibuan, Malayu S.P. (2002). Manajemen Sumber Daya Manusia. Bumi Aksara. Jakarta.

Handoko, T. Hani. (2001). Manajemen Personalia dan Sumberdaya Manusia. BPFE. Yogyakarta.

Hariandja, M.T.E. (2002). Manajemen Sumber Daya Manusia. Grasindo. Jakarta. Mangkunegara, Anwar Prabu. (2002). Manajemen Sumber Daya Manusia. PT. Remaja Rosda Karya, Bandung.

James A.F Stoner dkk Alih Bahasa Oleh Drs. Alexander Sindoro, (1996). Manajemen Sumber Daya Manusia. PT. Indeks, Gramedia Grup. Jakarta.

Edwin B. Flippo, (2002). Personel Management (Manajemen Personalia), Edisi VII Jilid II, Terjemahan Alponso S, Erlangga, Jakarta.

Subekti, R (1977). Aneka Perjanjian. Penerbit Alumni Bandung, Bandung.

Simamora, Henry, 2004, Manajemen Sumber Daya Manusia, Edisi Ketiga, Cetakan Pertama, Bagian Penerbitan STIE YKPN, Yogyakarta.

Sofyandi, Herman. (2008). Manajemen Sumber Daya Manusia, Edisi Pertama. Penerbit Graha Ilmu. Yogyakarta.

Sunyoto, Danang. (2012). Manajemen Sumber Daya Manusia, cet. I. CAPS. Yogyakarta.

S. Panggabean, Mutiara. (2004). Manajemen Sumber Daya Manusia, cet.2. Ghalia Indah. Bogor.

Solihin, Ismail. (2009). Pengantar Manajemen. Erlangga. Jakarta. Wijayanto, Dian. (2012). Pengantar Manajemen. PT Gramedia Pustaka Utama. Jakarta. 
Stephen P. Robbins dan Mary Coulter. (2010). Manajemen, Edisi 10 jilid I. Erlangga, Jakarta.

Tunggal, Amin Widjaja. (2008). Outsourcing Konsep dan Kasus. Harvarindo. Jakarta. 13 